Jurnal Ilmu-Ilmu Peternakan 25 (3): 53 - 58

ISSN: 0852-3681

E-ISSN: 2443-0765

CFakultas Peternakan UB, http://jiip.ub.ac.id/

\title{
Performans produksi burung puyuh (Coturnixcoturnix japonica) dengan perlakuan tepung limbah penetasan telur puyuh
}

\author{
Lukluil Maknun, Sri Kismiati dan Isna Mangisah \\ Fakultas Peternakan dan Pertanian Universitas Diponegoro \\ luleeljk@gmail.com
}

\begin{abstract}
The research aimed to evaluate the utilization of Japanese quail hatchery waste powder in feed on feed intake, egg production, egg mass and feed conversion ratio. The materials used were 4 weeks old 160 Japanese quails with an average weight of 94.19 \pm 7.36 gram. The experiment used a completely randomized design (CRD) with four treatments $(0 \%, 9 \%, 12 \%$, and $15 \%$ of Japanese quail hatchery waste powder in feed) and five replications. Parameters observed were feed intake, egg production, egg mass and feed conversion ratio. The data were analysed using analysis of variance and continued with Duncan's multiple range test 5\% level. The results showed that the addition of Japanese quail hatchery powder in feed had a significant effect $(\mathrm{P}>0.05)$ on feed intake and egg mass, but not on egg production and feed conversion ratio. The conclusion of this study was Japanese quail hatchery waste could be used on quail's feed until $15 \%$ without changing feed intake, egg production, egg mass and feed conversion ratio.
\end{abstract}

Keywords: Japanese quail hatchery waste, performance production, Japanese quail

\section{PENDAHULUAN}

Burung puyuh merupakan salah satu komoditi unggas yang semakin popular di Indonesia. Hal ini terbukti dengan banyaknya masyarakat yang berminat memelihara burung puyuh dan meningkatnya jumlah masyarakat yang mengkonsumsi produk-produk yang dihasilkan burung puyuh baik berupa telur maupun daging. Keunggulan burung puyuh lainnya adalah cara pemeliharaannyayang tidak sulit, cepat berproduksi dan memiliki daya tahan tubuh yang tinggi terhadap penyakit. Selain diambil telurnya, daging puyuh juga merupakan makanan yang lezat dan bernilai gizi tinggi. Telur puyuh mengandung $13,6 \%$ protein dan $8,2 \%$ lemak (Nugroho dan Mayun, 1990) yang tidak kalah dengan nilai gizi telur ayam ras yang mengandung $12,8 \%$ protein dan
$11,5 \%$ lemak (Direktorat Gizi Departemen Kesehatan RI, 1989). Populasi puyuh di Jawa Tengah sebanyak 4.741.170 ekor pada tahun 2013 dengan tingkat pertumbuhan sebesar $3,75 \%$. Produksi telur puyuh pada tahun 2013 yaitu $7.059 .767 \mathrm{~kg}$ dan 2,60\% diantaranya ditetaskan (Dinas Peternakan dan Kesehatan Hewan Provinsi Jawa Tengah, 2014).

Peningkatan potensi produksi burung puyuh memerlukan manajemen yang lebih baik terutama pakan berprotein tinggi. Sayangnya bahan pakan sumber protein merupakan bahan pakan yang paling mahal dibandingkan dengan yang lain sehingga menyebabkan biaya pakan juga tinggi.

Salah satu cara untuk menekan biaya pakan adalah dengan menggunakan bahan pakan non- 
konvensional diantaranya limbah. Menurut Salahudin et al. (1994), daya tetas puyuh (Coturnix coturnix japonica) yaitu $75,66 \%$ sehingga limbah yang dihasilkan oleh usaha penetasan puyuh sangat banyak dan akan menimbulkan masalah lingkungan jika tidak ditangani dengan baik. Limbah penetasan burung puyuh yang telah dikeringkan mengandung $36,24 \%$ protein kasar, $0,92 \%$ serat kasar, $10,73 \%$ kalsium, $0,69 \%$ fosfor serta asam amino esensial dan non-esensial. Penggunaan limbah penetasan dalam pakan sebanyak $8 \%$ dapat meningkatkan protein dan kalsium dalam pakan (Shahriar et al., 2008). Asam amino merupakan salah satu factor penting yang dibutuhkan dalam pembentukan telur (Sandilands and Hocking, 2012). Penggunaan 9\% tepung limbah penetasan telur puyuh dalam pakan tidak berpengaruh nyata terhadap produksi telur, berat telur, konsumsi pakan, efisiensi pakan, serta tingkat hidup puyuh breeder (Satishkumar and Prabakaran, 2008). Penelitian penggunaan tepung limbah penetasan telur puyuh pada level 9\%, 12\% dan $15 \%$ diharapkan dapat meningkatkan performans produksi burung puyuh.

\section{MATERI DAN METODE}

Penelitian ini dilaksanakan pada tanggal 20 Oktober - 12 Desember 2015di Desa Ketapang, Kecamatan Susukan, Kabupaten Semarang. Materi yang digunakan pada penelitian ini adalah puyuh betina umur 4 minggu sebanyak 160 ekor dengan berat rata-rata $94,19 \pm 7,36$ gram yang diperoleh dari peternakan di daerah Gajahan Kecamatan Colomadu, Kabupaten Karanganyar, Jawa Tengah. Kandang yang digunakan dalam penelitian ini adalah 2 kandang baterai yang memiliki ukuran PxLxT $200 \mathrm{~cm}$ x $50 \mathrm{~cm}$ x $30 \mathrm{~cm}$ dan dibagi menjadi 10 unit. Limbah penetasan telur puyuh diperoleh dari peternakan puyuh di daerah Singopuran Kecamatan Kartasura, Kabupaten Sukoharjo, Jawa Tengah. Limbah penetasan telur puyuh ini terdiri dari telur infertil, telur yang tidak menetas setelah 14 hari dan kerabang telur.

Bahan pakan yang digunakan terdiri dari jagung kuning, polard, bungkil kedelai, Poultry Meat Meal (PMM), premix, Monocalcium Phosphate (MCP), $\mathrm{CaCO}_{3}$ dan tepung limbah penetasan. Komposisi bahan pakan dan nutrien pakan yang digunakan dalam penelitian dapat dilihat pada Tabel 1 .

Limbah penetasan telur burung puyuh disortir dengan perbandingan 4 telur yang tidak fertil: 4 embrio yang gagal menetas: 2 cangkang telur. Proses selanjutnya yaitu limbah penetasan puyuh direbus dalam air panas bersuhu $80^{\circ} \mathrm{C}$ selama 1 jam. Limbah tersebut lalu ditiriskan dan dioven dalam suhu $80^{\circ} \mathrm{C}$ selama 3 jam lalu dijemur dibawah sinar matahari hingga kering kemudian dihaluskan hingga menjadi tepung. Perlakuan yang diberikan selama penelitian adalah sebagai berikut:

- $\mathrm{T} 0=$ pakan kontrol (tanpa tepung limbah penetasan)

- $\mathrm{T} 1=$ penggunaan tepung limbah penetasan $9 \%$ dalam pakan

- $\mathrm{T} 2=$ penggunaan tepung limbah penetasan $12 \%$ dalam pakan

- $\mathrm{T} 3=$ penggunaan tepung limbah penetasan $15 \%$ dalam pakan. 
Tabel 1. Komposisi dan kandungan nutrisi ransum penelitian

\begin{tabular}{|c|c|c|c|c|}
\hline \multirow{2}{*}{ Bahan pakan } & T0 & $\mathrm{T} 1$ & $\mathrm{~T} 2$ & $\mathrm{~T} 3$ \\
\hline & \multicolumn{4}{|c|}{ 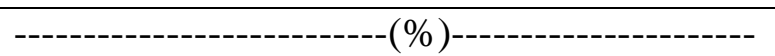 } \\
\hline Jagung & 45 & 47 & 45 & 44 \\
\hline Polard & 21 & 18 & 19 & 18 \\
\hline B. kedelai & 15,75 & 14 & 17 & 18 \\
\hline PMM & 11 & 6,75 & 2,25 & 1 \\
\hline Premiks & 0,25 & 0,25 & 0,25 & 0,25 \\
\hline $\mathrm{CaCO}_{3}$ & 5 & 2,5 & 1,5 & 0,5 \\
\hline Monocalcium Phosphate (MCP) & 2 & 2,5 & 3 & 3,25 \\
\hline Tepung limbah penetasan (TLP) & 0 & 9 & 12 & 15 \\
\hline Total & 100 & 100 & 100 & 100 \\
\hline Energi metabolis ${ }^{\mathrm{a}}(\mathrm{kkal} / \mathrm{kg})$ & 3208,27 & 2953,49 & 2910,99 & 2910,51 \\
\hline Protein $\operatorname{kasar}^{\mathrm{b}}(\%)$ & 21,65 & 21,74 & 22,03 & 23,09 \\
\hline $\operatorname{Lemak}_{\text {kasar }}{ }^{\mathrm{b}}(\%)$ & 2,28 & 2,41 & 2,41 & 2,46 \\
\hline Serat $\operatorname{kasar}^{\mathrm{b}}(\%)$ & 7,57 & 9,78 & 9,85 & 9,32 \\
\hline $\mathrm{Ca}^{\mathrm{b}}(\%)$ & 2,81 & 2,88 & 3,04 & 3,07 \\
\hline $\mathrm{P}^{\mathrm{b}}(\%)$ & 0,38 & 0,36 & 0,40 & 0,40 \\
\hline $\operatorname{Lisin}^{c}(\%)$ & 0,9981 & 1,0124 & 1,0119 & 1,0128 \\
\hline $\operatorname{Metionin}^{\mathrm{c}}(\%)$ & 0,3062 & 0,3564 & 0,3758 & 0,3948 \\
\hline
\end{tabular}

Keterangan :

a. Rumus Balton (1967) EM (kkal/kg) $=40,81[0,87(\mathrm{PK}+2,25 \mathrm{x} \mathrm{LK}+\mathrm{BETN})+\mathrm{k}]$

b. Laboratorium Ilmu Nutrisi dan Pakan Fakultas Peternakan dan Pertanian Universitas Diponegoro, Semarang. 2016.

c. Dihitung berdasarkan Satishkumar dan Prabakaran (2009).

Data yang diukur meliputi
konsumsi pakan, produksi telur, konversi pakan dan massa telur. Pengambilan data konsumsi dan produksi telur dilakukan setiap hari selama masa penelitian. Parameter yang diamati terdiri dari:

a. Konsumsi pakan

Konsumsi pakan dihitung dengan cara pakan yang diberikan dikurangi sisa pakan tiap hari (gram/ekor/hari).

Konsumsi $=$ Pakan yang diberikan $($ gram $)-$ sisa pakan (gram)

b. Produksi telur

Produksi telur puyuh dihitung dari perbandingan jumlah telur (butir) yang dihasilkan tiap hari dengan jumlah puyuh betina (ekor) yang hidup dikalikan $100 \%$.
Produksi telur $=\frac{\text { Jumlah telur (butir) }}{\text { Jumlah puyuh yang hidup (ekor) }} \times 100 \%$

a. Massa telur

Massa telur dihitung dari produksi telur harian dikalikan bobot telur dibagi jumlah populasi.

Massa telur $=\frac{\text { Produksi telur (butir) } \mathrm{x} \text { bobot telur }(\text { gram })}{\text { Jumbh }}$

b. Konversi pakan

Konversi pakan merupakan kemampuan puyuh mengkonversi pakan menjadi telur yang dihitung setiap minggu selama penelitian (8 minggu). Konversi pakan dihitung dengan rumus :

Konversi pakan $=\frac{\text { Konsumsi pakan }}{\text { Massa telur }}$ 
HASIL DAN PEMBAHASAN

Pengaruh penggunaan tepung limbah penetasan telur puyuh (TLP) terhadap konsumsi pakan, produksi telur, massa telur serta konversi pakan dapat dilihat pada Tabel 2. Penggunaan tepung limbah penetasan dalam ransum berpengaruh nyata $(\mathrm{P}>0,05)$ meningkatkan konsumsi pakan serta massa telur, namun tidak terdapat pengaruh yang nyata $(\mathrm{P}<0,05)$ terhadap produksi telur serta konversi telur.

Tabel 2. Rerata konsumsi pakan, produksi telur, massa telur serta konversi pakan pada puyuh yang diberi pakan dengan tepung limbah penetasan telur puyuh

\begin{tabular}{lcccc}
\hline & \multicolumn{3}{c}{ Level TLP dalam ransum } \\
\cline { 2 - 5 } Parameter & $0 \%$ & $9 \%$ & $12 \%$ & $15 \%$ \\
\hline Konsumsi pakan (gram/ekor/hari) & $16,73^{\mathrm{c}}$ & $18,14^{\mathrm{ab}}$ & $18,12^{\mathrm{ab}}$ & $18,37^{\mathrm{a}}$ \\
Produksi telur (\%) & 57,83 & 58,65 & 59,08 & 60,72 \\
Massa telur (gram/ekor/hari) & $5,43^{\mathrm{b}}$ & $5,61^{\mathrm{b}}$ & $5,75^{\mathrm{ab}}$ & $6,08^{\mathrm{a}}$ \\
Konversi pakan & 1,76 & 1,87 & 1,85 & 1,80 \\
\hline
\end{tabular}

Keterangan: Superskrip berbeda pada baris yang sama menunjukkan perbedaan yang nyata $(\mathrm{P}>0,05)$.

\section{Konsumsi ransum}

Tabel 2 menunjukkan bahwa penggunaan TLP pada pakan berpengaruh nyata $(\mathrm{P}>0,05)$ meningkatkan konsumsi ransum. Hal ini disebabkan karena proses pengolahan limbah penetasan dengan cara direbus dan dioven. Proses memasak tersebut mengubah tekstur dari limbah, salah satunya daging puyuh yang tidak menetas, sehingga semakin tinggi level penggunaan tepung limbah penetasan maka tekstur pakan akan berubah dan mempengaruhi citarasa pakan. Hal tersebut sesuai dengan pendapat Carmody dan Wrangham (2009) yang menyatakan bahwa proses memasak daging dengan cara direbus dan dioven dapat mengubah tekstur pakan serta meningkatkan citarasa sehingga palatabilitas meningkat. Proses pengolahan tersebut juga mengakibatkan pakan menjadi mudah dicerna sehingga konsumsi pakan meningkat. Konsumsi pakan yang meningkat juga disebabkan karena kandungan lisin dalam tepung limbah penetasan. Lisin merupakan asam amino esensial yang bermanfaat untuk menstimulasi selera makan. Hasil penelitian yang dilakukan Harms dan
Russel (1998) menunjukkan bahwa peningkatan kadar lisin akan meningkatkan konsumsi pakan pada ayam broiler breeder.

\section{Produksi telur}

Tabel 2 menunjukkan bahwa penggunaan TLP pada pakan tidak berpengaruh nyata $(\mathrm{P}>0,05)$ terhadap produksi telur puyuh. Hal ini disebabkan oleh kandungan bulu-bulu halus dalam tepung limbah penetasan. Bulu unggas sebagian besar terdiri atas keratin yang digolongkan kedalam protein serat. Protein bulu unggas mempunyai ciri kaya asam amino bersulfur (sistin). Adapun sifat fisik keratin adalah tidak larut dalamair. Keratin juga sulit larut dengan pemanasan alkali dan tidak larut oleh enzim saluran pencernaan. Ikatan disulfida yang dibentuk antar asam aminosistin menyebabkan protein ini sulit dicerna oleh enzim proteolitik dalam saluran pencernaan (Aderibigbe and Church, 1983).

Produksi telur puyuh juga dipengaruhi oleh kecernaan protein kasar dalam pakan. Kecernaan protein kasar puyuh yang diberi perlakuan penggunaan tepung limbah penetasan 
dalam pakan sebanyak $0 \%, 9 \%, 12 \%$ dan $15 \%$ adalah sama, yakni antara 86,86$89,06 \%$. Hasil tersebut menunjukkan bahwa ketersediaan asam amino untuk pembentukan telur adalah sama, sehingga produksi telur yang dihasilkan sama.

\section{Massa telur}

Penggunaan TLP pada pakan berpengaruh nyata $(\mathrm{P}>0,05)$ meningkatkan konsumsi ransum (Tabel 2). Peningkatan massa telur dipengaruhi oleh konsumsi protein burung puyuh, bobot telur puyuh serta produksi telur puyuh. Protein merupakan salah satu faktor yang diperlukan pada pembentukan telur selain kalsium dan fosfor.

Peningkatan massa telur pada perlakuan penggunaan tepung limbah penetasan pada taraf $12 \%$ dan $15 \%$ juga disebabkan oleh meningkatnya konsumsi ransum sehingga diikuti oleh peningkatan konsumsi protein. Hal ini sesuai dengan pendapat Proudfoot et al. (1988) yang menyatakan bahwa semakin tinggi kandungan protein dalam pakan dapat menyebabkan peningkatan pada produksi telur serta berat telur yang juga meningkatkan massa telur.

\section{Konversi pakan}

Penggunaan TLP pada pakan tidak berpengaruh nyata $(\mathrm{P}>0,05)$ terhadap konversi pakan (Tabel 2). Hal ini disebabkan konsumsi pakan serta massa telur meningkat sehingga terdapat keseimbangan pada konversi pakan dan konversi pakan menjadi tidak berbeda nyata.

\section{KESIMPULAN}

Penggunaan tepung limbah penetasan pada level $0 \%, 9 \%, 12 \%$ dan $15 \%$ dalam pakan mengakibatkan peningkatan konsumsi serta massa telur namun tidak berpengaruh terhadap produksi telur serta konversi pakan.

\section{DAFTAR PUSTAKA}

Aderibigbe, A. O. and D. C. Church. 1983. Feather and hair meal for ruminant.I. Effect of degree of processing on utilization of feather meal. J. Anim. Sci. 56:1198-1207.

Carmody, R. N., R. W. Wrangham. 2009. The energetic significance of cooking. Journal of Human Evolution 57 (2009) 379-391.

Dinas Peternakan dan Kesehatan Hewan Provinsi Jawa Tengah. 2014. Statistik peternakan Provinsi Jawa Tengah tahun 2014. Ungaran.

Direktorat Gizi Departemen Kesehatan Republik Indonesia. 1989. Daftar komposisi bahan makanan. Penerbit Bharata. Jakarta.

Harms, R. H and G. B. Russel. 1998. Adding methionine and lysine to broiler breeder diets to lower feed costs. J. Appl Poultry Res. 7 :202218.

Nugroho, E., I. G. K Mayun. 1990. Beternak burung puyuh. Eka Offset. Semarang.

Proudfoot, F. G., H. W. Hulan, and K. B. McRae. 1988. Performance comparisons of phased protein dietary regimens fed to commercial Leghorns during the laying period. Poult. Sci. 67:14471454.

Salahudin, M., D. C. Paul., Q. M. E. Hugue. 1994. Effect of egg weight and pre-incubation holding periods on hatchability of Japanese Quail in different seasons. AJAS 1994 vol.7 (no.4):449-503.

Sandilands, V., P. M. Hocking. 2012. Alternative systems for poultry : health, welfare, and productivity. CAPI Publishing. UK. 
Satishkumar, A. and R. Prabakaran. 2008. Recycling of Japanese quail hatchery waste on egg production performance of quail breeders. Tamilnadu J. Veterinary\&Animal Sciences 4(4) 123-128.
Shahriar, H. A., K. Nazer-Adl, J. Doolgarishaf and $\mathrm{H}$. Monirifar. 2008. Effect of dietary levels of hatchery wastes in broiler. Journal of Animal Veterinary Advances 7 (1): 100-105. 